Open Access

\title{
The utilisation of e-learning facilities in the educational delivery system of Nigeria: a study of M-University
}

Sunday Chinedu Eze ${ }^{1,3^{*}}$, Vera Chinwendu Chinedu-Eze ${ }^{2}$ and Adenike Oluyemi Bello ${ }^{1}$

\footnotetext{
* Correspondence: sundayeze2010@ gmail.com

${ }^{1}$ Department of Business

Administration, Landmark University,

Omu-Aran, Kwara PMB 1001, Nigeria

${ }^{3}$ Department of Business

Administration, Landmark University,

P.M.B 1001 Omu-Aran, Kwara State,

Nigeria

Full list of author information is

available at the end of the article
}

\begin{abstract}
In spite of the constant innovative approaches adopted by teachers in western world, traditional approaches to teaching and assessments in Nigeria tertiary institutions have constantly been practiced. Most institutions are not able to fully utilize e-learning or get full advantages of it. This failure has hindered most teachers in using innovative teaching methodologies in delivering their lectures, and undertake rigorous research works. The study examines adoption and utilisation of elearning facilities by lecturers in Nigerian private tertiary institution. The study adopted qualitative approach to investigate the adoption and utilisation of elearning facilities by lecturers in a Nigerian private tertiary institution using 15 semistructured interviews from the academic staff of M-University. Raw data gathered were analysed using data driven thematic approach (a similar approach to grounded theory).The findings reveal that M-University's e-learning facilities are adequate and accessible to users, and most teachers are comfortable with utilisation of various facilities during classes compared to most public tertiary institutions although, the utilisation has not been maximised. However, attitude of users, inadequate internet facility, inadequate training of users affect the successful adoption. The study recommends that e-learning facilities should be constantly upgraded, and that $\mathrm{M}$ University should train their staff continuously to meet the constant advancements of the e-Learning facilities in order to maximize usage.
\end{abstract}

Keywords: E-learning adoption, E-learning facilities, Private universities, Nigeria, Thematic analysis, Education

\section{Introduction}

The emergence of information and communication technologies (ICTs) and the ubiquitous connectivity of internet and networks improve man's ingenuity and opportunities given that societies consciously depend on real-time information to be proactive and to discount the effects of environmental changes (Zhang et al., 2010; Bates and Jenkins, 2007; Al-Gahtani, 2016; Eze and Chinedu-Eze, 2018). Entities attempt to cope with disruptive technologies; they make huge investment in the state of the art ICT platforms owing to the need to build competitive advantage amidst decreasing cost of technologies in the contemporary information systems (IS) market (Chuang et al. 2009; Bhuasiri et al., 2012; Maldonado et al., 2011; Eze et al., 2013; Awa et al., 2011). ICT is an agent of socio-economic changes (Al-Gahtani, 2016) and a force for creative 
destruction in human existence (Wang, 2009; Kotler, 1984), especially in the educational milieu, where the academia and consultants progressed from providing simple teaching aids to interactive learning environments. Higher education institutions (HEIs) have embarked on rigorous programs that promote the use of ICTs for effective contact and online teaching and learning and for developing cognate skills needed to make socio-economic contributions in the knowledge world. Scholars (Hu and Hui, 2012; Bhuasiri et al., 2012; Naqvi, 2007) opine that the IT-based innovations (e.g., e-commerce, e-learning, e-payment, e-service, or e-procurement) revolutionize the HEIs' competitive landscape and reflect the dramatic evolution from fairly predictable brick-and mortar affairs to rapidly changing and often more unpredictable environment. E-learning is one of the most significant educational innovations driven by expanding array of technology enabled platforms that offer potential learners an alternative and innovative learning environment compared with traditional learning and, thus, represents IT-based innovation in education (Bates, 2007; Wang, 2009).

While some use e-learning to refer to pieces of content packaged using technical infrastructures, others consider it an on-line self-study, and yet others see it as encompassing on-going learning and joint effort. E-learning or computer-based learning is a learning process that involves the connection of digitally conveyed content, system-based administrations and mentoring bolster (Zhang et al., 2010; Markus and Robey, 1998). With Tom Friedman's mantra of the world is flat driven by ICT platforms, e-learning salvages HEIs given that they can rarely assemble trainees and students at a single location and get them trained on new systems, products or processes. Further, studies (Keramati et al., 2011; Bhuasiri et al., 2012; Chen and Tseng, 2012; Ahmed, 2010; Hu and Hui, 2012) show that e-learning adoption by vast number of HEIs, professional organizations and learners is motivated by geographical and savvy remote reach, separate learning environment, juicy paybacks/returns, continuous upgrades of skills within a short time, learners' control in terms of adaptability, flexibility and convenience, and cost effectiveness in course/programme delivery and management. In the developing countries, HEIs are facing poor funding and dearth of qualified staff, resources and access to educational materials (Ahmed, 2010; Al-Gahtani, 2016; Eze et al., 2012) compared to those in the developed economies and they perceive that e-learning, with all its potentials, pools resources and develops quality materials to alleviate the shortcomings of their traditional education strategies and make the HEIs more competitive since instructors are empowered to exchange their ideas with students devoid of restrictions on space, time or facilities (Bhuasiri et al., 2012; Bates, 2007; Fu et al., 2007). However, in spite of the obvious advantages of e-learning adoption in the developing economies, its adoption is rather too low because of the high illiteracy rate and poor educational funding by the federal and state government.

\section{Problem statement}

In Nigeria, the continual reduction of education budget to abysmal 8\% in the 2017 budget and the attendant rationing of funds amongst greater number of public HEIs amidst stiff competition coming from private HEIs, suggests each HEI should turn to e-learning as a strategic source of socio-economic sustenance (Aboderin and Kumuyi, 2013). However, in spite of the fact that University of Port Harcourt as one of the first 
Nigerian universities to venture into e-learning, partnered with the University of Nairobi, Kenya to launch open and distance learning (ODL) in some specific disciplines the programme has some difficulties of poor awareness and poor infrastructures and abysmal management commitment to interactive knowledge environment (Bukhari, 2010). Also, this institution and many others may have suffered limited resources and awareness, inadequate manpower and training, instability in energy, and poor internet and network facilities in their bid to exploit complete utilization of e-learning facilities (Markus and Robey, 1998; Bhuasiri et al., 2012; Bukhari, 2010; Allen and Seaman, 2003). Although, all HEIs in Nigeria have connected to the internet that facilitate e-payment of school fees, e-library, e-registration, and e-payroll coupled with the constant innovation and the innovative approaches adopted by teachers in western world, most studies have focused on public HEIs while private HEIs have been largely ignored. Therefore, traditional approaches to teaching and assessments in these Universities have been constantly used while e-learning is yet to be used amongst them (Anene et al., 2014; Bukhari, 2010; Singh and Hardaker 2014). Barriers such as poor awareness, poor infrastructures and abysmal management commitment to interactive knowledge environment (Bukhari, 2010) have been hindering most instructors/teachers from using innovative teaching methodologies in delivering lectures and undertaking rigorous research work (Bukhari, 2010; Singh and Hardaker, 2014; Ahmed, 2010; Hu and Hui, 2012; Fu et al., 2007). Although some universities and more especially the private ones(Aboderin and Kumuyi, 2013) are attempting to embrace complete utilization of e-learning facilities by committing funds for the procurement of these facilities, however, they have failed to accomplish this objective (Bukhari, 2010).

Therefore, this paper examines the nature of adoption of e-learning facilities and the critical factors that influence such adoption in a private higher institution in Nigeria. This is driven by the fact that most studies in Nigeria focused on accessibility of e-learning facilities, problems and prospect in public institutions (Anene et al., 2014; Aboderin and Kumuyi, 2013) while its adoption and utilisation in the educational delivery system of private tertiary institutions in Nigeria have been largely ignored. Furthermore, most studies (see Zhang et al., 2010; Hu and Hui, 2012; Al-Gahtani, 2016) have sought to regularly adopt quantitative methods, while qualitative and inductive case study, grounded theory, thematic analysis or sentimental analysis have been largely ignored. Therefore, more studies are required in this area using a different methodological approach.

\section{Literature review}

\section{The concept of e-learning}

The term e-learning defines technology mediated and digitally empowered learning that utilizes hardware (e.g., PCs, tablets, printer, digital camera, digital videos, scanner, overhead projector; OHP, and OHP screen), software (operating systems, cloud technologies, applications (apps), writing, editing, MS Office) and (CD textbooks that fall in the category of courseware, OERS, e-content) and others (e.g., USB drives, CD-ROM), whether from a distance or face-to-face classroom setting (PC helped learning), to empower teacher to student interactions. Actually, it moves the citadel of learning from traditional to module-driven, ICT-based customized, adaptable and synergistic learning 
that involves learners, instructors, facilitators, and specialists (Falana, 2015; Markus and Robey, 1998; Olojo et al., 2012). While the traditional was teacher focused, the learner focus is facilitated by technology affordances which empowers learners in sharing and receiving contents regularly. E-learning encompasses simplified and synergistic PC bolstered learning process and appraisal approaches that utilize innovation and other programming such as wikis, blogs, podcasts and learning management frameworks (e.g., internet and web offices -www) to improve teaching and research (Mahahusudhan, 2008; Nadiu, 2006) and to empower students and teachers to produce, progress, and share learning contents in a more regular structure (Chiaha et al. 2013).

Studies (e.g., Falana, 2015; Markus and Robey, 1998; Olojo et al., 2012; Sloan et al., 2014) argue that e-learning is a significant and compelling strategy that should be introduced into institutions' current learning style and teaching method for students and for community oriented learning. Markus and Robey (1998) affirms that learning and mentoring of students are done using the PC as a learning process which involves digitally conveyed contents, system based administrations and coaching support. The use of e-learning strategy to execute educational contents and modules in Nigeria's HEIs makes for educator-student dynamism in the ways of instructing and learning of the substances (Liverpool et al., 2010). Kajetanowtez and Wierzejewski (2010) perceive e-learning as productive method that advances self-study cum continuous testing and developmental assessments which incite legitimate checking of instructive advancement and periodic accomplishment. General examination report demonstrates that e-learning gives beneficial outcome on learners' accomplishments. Garrison and Anderson (2003) assert that the utilization of e-learning helps learners' willingness to learn to innovate. Learners introduce atmospheres where interests are stirred, creative abilities invigorated, premiums produced, perspectives developed and states of mind changed along the lines of achieving the premise for instruction. Asserts that the advantages of e-learning to organizations and lecturers is that it reduces time and cash, upgrades image of the institution, advances ceaseless expert advancement of staff, enhances the nature of education and makes adaptation more powerful.

Richmond (1997) notes that there is a connection between the educational programs and ICT and that there are three ways technology can impact learning:

- presentation, exhibition and the execution of information utilizing efficiency devices;

- use of educational modules - particular applications, for example, instructive games, drills and practice, simulations, instructional exercises, virtual lab perceptions and illustrations, representations of unique ideas, musical piece and master frameworks; and

- use of information and assets on CD-Rom, online reference book, intuitive maps and chart books, electronic diaries and different references.

However, the socio-economic potentials of the teaching methodology of e-learning precipitate its fast adoption especially in the western world, where many HEIs see e-learning programmes as cash-cow venture. In addition, as the teaching landscape is changing rapidly because of the rise in technology in the twenty-first century and the integration of technologies into the society coupled with access to the internet, the way teaching is carried out in HEIs has changed especially in the western world. 
Blended learning technique (the combination of frequently eLearning and traditional face-to-face learning) has been adopted in HEIs. This approach guarantees that the learner is involved in driving his or her individual learning experience. This method assists and caters for individual needs of the learner than the traditional classroom teaching experience because most students have unique learning styles. However, this approach is yet to be predominant in Nigeria.

\section{E-learning adoption in Nigerian institutions}

HEIs in Nigeria are to adopt e-learning to change the old strategies and ways they deal with educational program's execution. E-learning is driven by educational modules via the PC and the web. The HEIs in Nigeria mostly adopt e-learning facilities in the form of arranged addresses on a CD-ROM that can be played when the need arises. This restricts interest as a result of unsatisfactory student-PC ratio (large number of students per PC) that confirms insufficient greater parts of cognate facilities. The intranet facilities in many schools are inadequate because of the high cost of running the facilities often occasioned by the unstable power supply, which exposes most students to public internet cyber-cafes. The bandwidth shared on different frameworks at the bistros is low thus; a media intuitive address will not be possible in view of low bandwidth. Aside the usual obstructions and risks associated with e-learning in Nigeria, some areas within a typical HEI rarely enjoy network accessibility. Salawudeen (2006) argues that though vast majority of HEIs in Nigeria have begun building their ICT centres, the centres are primarily set up as a web office without considering most facilities that make up e-learning centres. Researchers and analysts in Nigeria have shown interest in HEIs' adoption of e-learning because its tons of barriers. One of such barriers is the instructors' inability to assist students build up capacity and information needed to make them utilize e-learning facilities adequately. In addition, students are confronted with other difficulties amidst their studies; there are absence of teaching methods in their educational programs, absence of user touch and feel in their e-learning stage, absence of vision and structure in executing e-learning (Kizito and Bijan, 2006; Oguzor, 2011), lack of specialized and social aptitudes required for the execution of e-learning and disappointment experienced in e-learning establishment.

Using the University of Abuja, Nigeria as case point, Anene et al. (2014) studied the problems and prospects of e-learning in Nigerian Universities by specifically examining availability of facilities for e-learning and availability of e-learning materials and to ascertain if students make use of e-learning in their studies. They found that one of the obstacles to the use of ICT was infrastructure deficiencies; the students lamented that Nigerian Universities do not have adequate e-learning library domain, online seminars or discussion with lecturers, online examination, and limited bandwidth. Implicit of this study was continual strikes by Academic Staff Union of Nigerian University (ASUU) to force governments to correct abnormalities. Chiaha et al. (2013) explicitly studied the kind of e-learning facilities that students have access to; the percentage and extent students access these facilities as well as the factors that hinder students from accessing e-learning facilities. The result revealed that about $42.9 \%$ of the students had access to e-learning facilities; most students have access to only e-mail accounts and the factors hindering access to e-learning facilities include irregular electric power supply, poor 
network connection, among others (Chiaha et al., 2013). Atsumbe et al. (2012) investigated the availability and utilization of e-learning infrastructures in a Nigerian University. Their specific objectives were to investigate the adequacy of e-learning infrastructures for effective teaching and learning; the proficiency of e-learning infrastructures to facilitate enhanced lecturer-student teaching and learning interactions; and the factors that inhibit the use of e-learning infrastructures. The findings revealed that there were inadequate facilities specifically directed toward teaching and learning and the e-learning infrastructure available is largely for administrative use, although lecturers and students have access to computers or laptops internet facilities they are not used for teaching and learning.

Aboderin and Kumuyi (2013) looked at the problems and prospects of e-learning in curriculum development and implementation in secondary schools in Ondo State of Nigeria. Specifically, they examined the availability of e-learning tools for curriculum implementation, the extent to which it was applied by teachers, strategies and prospects of e-learning in secondary schools. The finding revealed that there were shortages of e-learning tools and the few ones used were not adequately used. On the strength of these, the investigators advised governments to embark on massive in-service training and retraining (seminars, symposia, workshops and conferences) for teachers on how to operate computers. Similarly, Aboderin (2015) investigated the challenges and prospects of e-learning at the National Open University of Nigeria and while the study recognized that e-learning influences students' ICT competence, it found that the major challenges included lack of enough computers, shortage of internet facilities, students' lack of access to e-learning facilities and tools, high cost of software and erratic power supply.

\section{E-learning adoption in private HEls}

The number of existing private HEIs in Nigeria is quite on buzz, almost out-numbering their public counter-parts and so is the rate of adopting modern technologies. Private HEIs in Nigeria may be more IT-driven than public HEIs. However because private HEIs are self-financing and considered small since it is owned by few persons, it is assumed they have greater operating agility and make faster adoption decisions than public HEIs. The self-financing characteristics justifies why private HEIs should be ahead of public HEIs in exploiting the huge socio-economic potentials of e-learning. HEIs in Nigeria and some other developing economies are to be in the frontline of leveraging from e-learning because many of them suffer poor funding. The private HEIs are even better positioned to leverage on e-learning strategy to deal with their supposed financial setbacks but the situation as it is in Nigeria and some other developing nations rarely allows any HEIs (whether private or public) to maximally exploit the full potentials of e-learning. The private HEIs may be more disposed to adopt owing to their ownership and goal patterns but may be cut short by the obvious barriers of network and power fluctuations, limited resources, and poor societal awareness and enlightenment. Nevertheless, the institutions are making some head-ways, no matter how little.

In summary, the level of e-learning adoption in Nigerian HEIs is low. Although most public HEIs have attempted to build ICT based centres for e-learning adoption, most 
of these established centres are web based centres without adequate e-learning facilities. Some of the reasons for low e-learning adoption in these universities range from lack of mission, vision and structure in implementing e-learning, disappointment of e-learning establishment, lack of specialized and social aptitudes required for the execution of e-learning and teachers to lack of teachers and students knowledge and the know-how to use e-learning platforms. Although, both the state and federal government have made some efforts in providing trainings to most public universities, the fundS and training provided are inadequate coupled with the alarming level of corrupt practices going on in most Public HEIs. This may explain why the Private HEIs may have the greater operating and faster e-learning adoption because of their self-financing characteristics and the proprietors of these institutions would go extra mile to ensure that such facilities are in place and implemented based on the goals, mission and vision.

\section{Methodology}

Most ICT and e-learning adoption studies mainly employed case study and survey approach which have dominated the Information Systems (IS) field. For example, studies (Orlikowski and Baroudi, 1991; Choudrie and Dwivedi, 2005) argued that case study, experimentation and survey methods are mostly used in IS research. According to Choudrie and Dwivedi (2005) out of 633 articles in top IS journals: ISJ, EJIS ISR and MIS Quarterly analysed between 1994 and 2003, 74\% of most researchers in IT and e-learning adoption studies often adopt survey approach. It is argued that quantitative research approach often remains unquestioned; when there are irregularities in the theory used, it is attributed to other factors, such as the instruments, sampling and sample size (Silver, 2007).Therefore, qualitative method was an alternative approach and provides richer results because IT adoption research requires not just explanatory theories but methods that can help explain phenomena in broader ways (Silva 2007; Lee 2003; Elliot and Loebbecke, 2000). Hence, this study adopts qualitative approach in an attempt to bridge this gap and to examine the adoption and use of e-learning facilities in the educational delivery system of a Nigerian private tertiary institution. Data driven approach of thematic analysis was adopted for this research in order to generate unique themes and code from scratch which most traditional adoption theories (e.g intentional based theories and behavioural based theories) have failed to do, which form the basis for the study. Descriptive research design was adopted because the research adopted qualitative approach with the use of interview. The population of this study are the academic staff of the three (3) colleges in 'M' University; which includes College of Agricultural Sciences (CAS), College of Business and Social Sciences (CBS) and College of Science and Engineering (CSE).

The initial sample of 65 participants was generated of which 15 (5 each) from the three (3) colleges in ' $M$ ' University agreed to be interviewed (Table 1 of the interview profile). The sampling technique used in this study is purposive sampling (a non-probability sampling) which is based on the knowledge and understanding of the population, and allows the researcher to select individuals who may fully understand the subject matter.

Before the interview, letters were sent to the participants ahead of time requesting their consent to be interviewed. Upon approval received, the purpose of the study was stated before commencing the interview proper. The interviewees were reassured of their confidentiality since the information provided would not be disclosed to a third 
Table 1 Interviewee profile

\begin{tabular}{lll}
\hline Interview participants & College & Organizational status \\
\hline A1 & CAS & LECTURER ॥ \\
A2 & CBS & LECTURER ॥ \\
A3 & CAS & SENIOR LECTURER \\
A4 & CSE & LECTURER ॥ \\
A5 & CSE & ASSITANT LECTURER \\
A6 & CAS & PROFESSOR \\
A7 & CAS & LETURER I \\
A8 & CBS & LECTURER ॥ \\
A9 & CSE & LECTURER I \\
A10 & CAS & ASSITANT LECTURER \\
A11 & CBS & LECTURER ॥ \\
A12 & CBS & ASSITANT LETURER \\
A13 & CSE & LECTURER ॥ \\
A14 & CBS & ASSISTANT LECTURER \\
A15 & CSE & LECTURER ॥ \\
\hline
\end{tabular}

party and results generated will be shared and respondents answers shared will be anonymous. Their permission to record the conversation using audio tape recorder was sought. The interview was scheduled for $30 \mathrm{~min}$ per interviewee. Finally the responses from the participants were transcribed. Some of the questions asked during the interview were; what are the types of e-learning facilities M-University lecturers use in delivering lectures to students?; Are e-learning facilities in M-University adequate enough for lecturers to use in delivering lectures to students?; How would you describe the utilization of e-learning facilities in M-University by lecturers?; Do you always feel comfortable using e-learning facilities when delivering lectures to students?; Do you think that e-learning facilities are simple and easy to use?; Have e-learning facilities helped in improving your lecturing performance?; Do you prefer the use of e-learning facilities to "face to face" learning in delivering lectures to students?; What do you think are the major factors that inhibit the adoption of e-learning facilities by lecturers in M-University?;

\section{Data analysis}

This section shows a systematic approach on how the findings were derived. Figure 1 below represents data analysis process. The data analysis process employed in this study is thematic analysis. More specifically, data driven thematic analysis approach was adopted since the codes were generated from the raw data. This approach was useful in the research because it allows the application of data driven codes to the raw data and themes to emerge inductively and aids credibility and dependability checks (see Miles and Huberman, 1994). In stage one to three of the data analysis process, codes generated in the initial interviews were applied on the raw data to check how credible they are. In stage four, all the transcribed data was imported into NVivo to further facilitate the analysis because of the huge data involved. This helped in the management of the data using a practical guide developed for coding the data (see Tables 2, 3 and 4). Finally, the model which helped in the interpretation of findings were developed. 


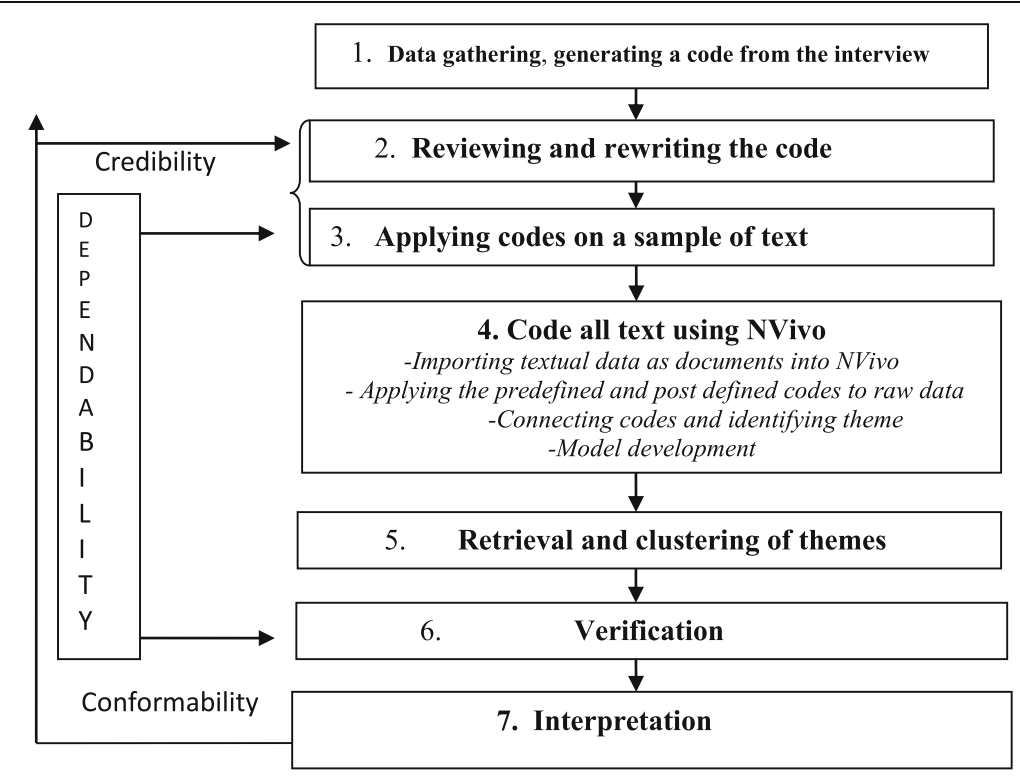

Fig. 1 Data Analysis Process

\section{General guide for generating code \\ Verification}

Drawing on Boyatzis (1998), the study was validated by presenting the data to experts in the field who further cross-checked the patterns in the data against the themes that emerged during the study. The data analysis process was part of design method which revealed how data was analysed and reported (dependability check) followed by a conformability checks to ascertain how tightly the raw data is linked to the interpretation (see Boyatzis, 1998). Inter-rater reliability using percentage agreement was adopted. Table 5 shows the result of the reliability analysis involving percentage agreements (see Boyatzis, 1998; Miles and Huberman, 1994) which was gotten from two judges that rated the codes to see if they corresponded with the definitions of codes and their associated supporting evidences. The analysis reveals that the percentage agreement for the scope of the study was above the 70\% benchmark as recommended by Miles and Huberman (1994).

Table 2 Adequate e-learning facilities and lecturers level of utilisation

\begin{tabular}{|c|c|c|}
\hline Codes & Definition & Description \\
\hline \multicolumn{3}{|c|}{ Adequate e-learning facilities } \\
\hline $\begin{array}{l}\text { Availability } \\
\text { of e-learning } \\
\text { facilities in use }\end{array}$ & $\begin{array}{l}\text { The capacity of e-learning facilities } \\
\text { to be accessible and adequate for } \\
\text { use }\end{array}$ & $\begin{array}{l}\text { This is indicated when respondents mention that } \\
\text { there are quite a number of e-learning facilities } \\
\text { available in M University. }\end{array}$ \\
\hline $\begin{array}{l}\text { Adequate } \\
\text { e-learning facilities } \\
\text { in use }\end{array}$ & $\begin{array}{l}\text { Satisfactory use of e-learning } \\
\text { facilities in delivering lectures }\end{array}$ & $\begin{array}{l}\text { This is indicated when respondents mention that } \\
\text { the e-learning facilities are adequate in delivering } \\
\text { lectures to students }\end{array}$ \\
\hline \multicolumn{3}{|c|}{ Utilization of e-learning facilities } \\
\hline $\begin{array}{l}\text { Utilization } \\
\text { of e-learning } \\
\text { facilities }\end{array}$ & $\begin{array}{l}\text { Average utilisation of e-learning } \\
\text { facilities }\end{array}$ & $\begin{array}{l}\text { This is indicated when respondents mention that e- } \\
\text { learning facilities are to some extent used by } \\
\text { lecturers. }\end{array}$ \\
\hline
\end{tabular}


Table 3 Preference and ease of e-learning adoption over 'face to face' method

\begin{tabular}{|c|c|c|}
\hline Codes & Definition & Description \\
\hline \multicolumn{3}{|c|}{ 'Ease of use of e-learning adoption facilities } \\
\hline $\begin{array}{l}\text { At ease in the } \\
\text { use of e-learning } \\
\text { facilities }\end{array}$ & $\begin{array}{l}\text { The utilization of e-learning facilities } \\
\text { when delivering lectures to students } \\
\text { is encouraging }\end{array}$ & $\begin{array}{l}\text { This is indicated when respondents mention } \\
\text { that the use of e-learning facilities is } \\
\text { encouraging }\end{array}$ \\
\hline User friendly & E-learning facilities are simple to use & $\begin{array}{l}\text { This is indicated when respondents mention } \\
\text { that e-learning facilities are simple to use }\end{array}$ \\
\hline $\begin{array}{l}\text { Significant } \\
\text { improvement }\end{array}$ & $\begin{array}{l}\text { E-learning facilities has made } \\
\text { weighty progress in improving } \\
\text { lecturing performance }\end{array}$ & $\begin{array}{l}\text { This is indicated when lecturers attested to } \\
\text { the fact that their teaching performance has } \\
\text { improved significantly }\end{array}$ \\
\hline \multicolumn{3}{|c|}{ Preference of e-learning over 'face to face' method vs preference of 'face to face' over e-learning over method } \\
\hline $\begin{array}{l}\text { E-learning supports } \\
\text { 'face to face' method }\end{array}$ & $\begin{array}{l}\text { E-learning compliments 'face to } \\
\text { face' }\end{array}$ & $\begin{array}{l}\text { This is indicated when respondents mention } \\
\text { that e-learning compliments each other }\end{array}$ \\
\hline $\begin{array}{l}\text { 'Face to face' } \\
\text { method preferred } \\
\text { over e-learning method }\end{array}$ & $\begin{array}{l}\text { Face to face method is chosen over } \\
\text { e-learning method }\end{array}$ & $\begin{array}{l}\text { This is indicated when respondent mention } \\
\text { that they prefer 'face to face' method over } \\
\text { e-learning method }\end{array}$ \\
\hline
\end{tabular}

\section{Findings and discussion}

The findings presented in Tables 6, 7, 8 and 9 depict the codes, themes and the supporting evidences. Boyatzis (1998) identified three approaches of thematic analysis - data driven, theory driven and hybrid approach. We adopted data driven approach because themes were clustered based on the codes generated from the raw data. The findings presented below are based on the narratives of participants, codes generated from the raw data and relevant literature.

\section{Availability of e-learning facilities}

The availability and adequacy of e-learning facilities is one of the basic requirements of its adoption in $M$ University. It was discovered that there are various types of e-learning facilities available in M University; they include projectors, PCs, e-library and so on. Also, majority of the lecturers noted that the e-learning facilities in M-University are adequate and the facilities should be regularly updated and maintained. M-University has several facilities that are used in delivering lecturers and assessing students. Some participants identified power points, projectors and the e-learning platform created by the University's Centre for System and Information Services (CSIS) which provided bases for interactions with students by uploading course compacts online. Such platform is used to upload quiz, assignments and so on.

Table 4 Key factors inhibiting the adoption of e-learning facilities

\begin{tabular}{|c|c|c|}
\hline Codes & Definition & Description \\
\hline \multicolumn{3}{|c|}{ Major factors inhibiting the adoption of e-learning facilities } \\
\hline $\begin{array}{l}\text { Attitudes } \\
\text { of users }\end{array}$ & $\begin{array}{l}\text { The attitudes of the users } \\
\text { affect e-learning adoption }\end{array}$ & $\begin{array}{l}\text { This is indicated when respondents identifies attitudes of } \\
\text { users as a limiting factor in adoption of e-learning }\end{array}$ \\
\hline $\begin{array}{l}\text { Inadequate } \\
\text { internet facility }\end{array}$ & $\begin{array}{l}\text { Poor internet service affects e- } \\
\text { learning adoption }\end{array}$ & $\begin{array}{l}\text { This is indicated when respondents mention that } \\
\text { inadequate internet access affects e-learning adoption }\end{array}$ \\
\hline $\begin{array}{l}\text { Inadequate } \\
\text { training of users }\end{array}$ & $\begin{array}{l}\text { Insufficient training of users } \\
\text { affects e-learning adoption }\end{array}$ & $\begin{array}{l}\text { This is indicated when respondents mention that } \\
\text { inadequate training of users inhibits e-learning adoption }\end{array}$ \\
\hline
\end{tabular}


Table 5 Reliability analysis

\begin{tabular}{|c|c|c|}
\hline \multirow[t]{2}{*}{ Areas of the study } & \multicolumn{2}{|l|}{ Reliability } \\
\hline & Judge 1 & Judge 2 \\
\hline \multirow{4}{*}{$\begin{array}{l}\text { Adequate and utilisation of e-learning Facilities } \\
\text { and lecturers level of utilisation }\end{array}$} & \multicolumn{2}{|c|}{ Adequate e-learning facilities in M-University } \\
\hline & $(0.883) 88.3 \%$ & (0.889) 88.9\% \\
\hline & \multicolumn{2}{|c|}{ Utilization of e-learning facilities } \\
\hline & (0.917) 91.7\% & $(0.95) 95 \%$ \\
\hline \multirow[t]{4}{*}{ Preference and ease of e-learning adoption } & \multicolumn{2}{|c|}{ Comfortable using e-learning } \\
\hline & $(0.88) 88 \%$ & $(0.79) 79 \%$ \\
\hline & \multicolumn{2}{|c|}{ Preference of e-learning } \\
\hline & $(0.82) 82 \%$ & $(0.75) 75 \%$ \\
\hline \multirow[t]{2}{*}{ Key factors inhibiting the adoption of e-learning facilities } & \multicolumn{2}{|c|}{ Factors inhibiting the adoption of e-learning } \\
\hline & (0.95) 95\% & $(0.88) 88 \%$ \\
\hline
\end{tabular}

"It is expected of every lecturer in M-University to deliver their lectures through the power point... then you know we have the e-learning platform on the M-University portal..."

(A1). Similarly, participants: A2, A3 and A7 made similar statements.

Finally, one of the lecturers mentioned that Departments across colleges in M-University have their own websites where students can get to know what the department stands for in terms of their philosophy, core values and standards. Students can

Table 6 Adequate e-learning Facilities and lecturers level of utilisation

\begin{tabular}{|c|c|c|c|}
\hline Code & Themes & Total Supporting Cases & \\
\hline \multirow[t]{2}{*}{$\begin{array}{l}\text { Availability/ Adequate } \\
\text { of e-learning facilities in use }\end{array}$} & $\begin{array}{l}\text { Availability of sufficient } \\
\text { e-learning facilities for usage }\end{array}$ & $\begin{array}{l}\mathrm{A} 1, \mathrm{~A} 2, \mathrm{~A} 3, \mathrm{~A} 4, \mathrm{~A} 5, \mathrm{~A} 6, \mathrm{~A} 7, \mathrm{~A} 8, \mathrm{~A} 9, \\
\mathrm{~A} 10, \mathrm{~A} 11, \mathrm{~A} 12, \mathrm{~A} 13, \mathrm{~A} 14, \mathrm{~A} 15\end{array}$ & $\begin{array}{l}15 / \\
15\end{array}$ \\
\hline & $\begin{array}{l}\text { Adequate e-learning facilities } \\
\text { for use }\end{array}$ & $\begin{array}{l}A 1, A 4, A 5, A 6, A 7, A 10, A 12, A 13, A 14 \\
A 15\end{array}$ & $\begin{array}{l}10 / \\
15\end{array}$ \\
\hline $\begin{array}{l}\text { Utilization of e-learning facilities } \\
\text { by M University lecturers }\end{array}$ & Average utilization & $A 2, A 5, A 6, A 7, A 9, A 11, A 12, A 13, A 14$ & $\begin{array}{l}9 / \\
15\end{array}$ \\
\hline \multicolumn{4}{|c|}{ Preference and ease of e-learning adoption } \\
\hline \multirow[t]{3}{*}{$\begin{array}{l}\text { Ease in the use of e-learning } \\
\text { facilities }\end{array}$} & At ease in using e-learning facility & $\begin{array}{l}A 1, A 2, A 3, A 4, A 6, A 7, A 8, A 10, A 13, \\
A 15\end{array}$ & $\begin{array}{l}10 / \\
15\end{array}$ \\
\hline & User friendly & $\begin{array}{l}A 1, A 2, A 4, A 5, A 7, A 8, A 9, A 10, A 11, \\
A 12, A 14, A 15\end{array}$ & $\begin{array}{l}15 / \\
15\end{array}$ \\
\hline & Significant improvement & $\begin{array}{l}\mathrm{A} 1, \mathrm{~A} 2, \mathrm{~A} 3, \mathrm{~A} 4, \mathrm{~A} 5, \mathrm{~A} 6, \mathrm{~A} 7, \mathrm{~A} 8, \mathrm{~A} 9 \\
\mathrm{~A} 10, \mathrm{~A} 11, \mathrm{~A} 12, \mathrm{~A} 13, \mathrm{~A} 14, \mathrm{~A} 15\end{array}$ & $\begin{array}{l}15 / \\
15\end{array}$ \\
\hline \multirow[t]{2}{*}{$\begin{array}{l}\text { Preference of e-learning } \\
\text { over 'face to face' method }\end{array}$} & $\begin{array}{l}\text { E-learning supports 'face } \\
\text { to face' method }\end{array}$ & $A 3, A 4, A 7, A 9, A 10, A 14$ & $\begin{array}{l}6 / \\
15\end{array}$ \\
\hline & $\begin{array}{l}\text { 'Face to face' method preferred } \\
\text { over e-learning method }\end{array}$ & $A 5, A 6, A 8, A 11, A 12, A 13$ & $\begin{array}{l}6 / \\
15\end{array}$ \\
\hline \multicolumn{4}{|c|}{ Major factors inhibiting the adoption of e-learning facilities } \\
\hline & Codes & Total Supporting Cases & \\
\hline \multirow[t]{3}{*}{ Inhibiting factors } & Attitudes of users & $A 1, A 7, A 9, A 10, A 11, A 12, A 15$ & $\begin{array}{l}7 / \\
15\end{array}$ \\
\hline & Inadequate internet facility & $A 1, A 2, A 4, A 8, A 9, A 11, A 14$ & $\begin{array}{l}7 / \\
15\end{array}$ \\
\hline & Inadequate training of users & $A 3, A 6, A 7, A 8, A 10, A 13, A 14$ & $\begin{array}{l}7 / \\
15\end{array}$ \\
\hline
\end{tabular}


Table 7 Adequate e-learning Facilities and lecturers level of utilisation

\begin{tabular}{|c|c|c|}
\hline Codes & Themes & Sample supporting evidences \\
\hline \multirow[t]{2}{*}{$\begin{array}{l}\text { Adequate e-learning } \\
\text { facilities in M University }\end{array}$} & $\begin{array}{l}\text { Availability of sufficient } \\
\text { e-learning facilities in use }\end{array}$ & $\begin{array}{l}\text { "It is expected of every lecturer in M University to deliver } \\
\text { their lectures through the power point" (A1) } \\
\text { "Each department has its own website... they also have a } \\
\text { platform for the e-learning... we also have laptops to aid } \\
\text { our typing, and projector". (A12) }\end{array}$ \\
\hline & $\begin{array}{l}\text { Adequate e-learning } \\
\text { facilities in use }\end{array}$ & $\begin{array}{l}\text { "We have enough... New facilities shouldn't be introduced } \\
\text { at the moment except for the consistence of the internet, } \\
\text { then accessing of the e-book". (A1) } \\
\text { "Very adequate noting should be added because we have } \\
\text { not even utilized fully the ones that we have". (A12) }\end{array}$ \\
\hline $\begin{array}{l}\text { Utilization of e-learning } \\
\text { facilities by M University } \\
\text { lecturers }\end{array}$ & Average utilization & $\begin{array}{l}\text { "I would say we use it on the average". (A2) } \\
\text { "Averagely used". (A9) }\end{array}$ \\
\hline
\end{tabular}

equally download the departmental handbook which contains the course codes and course outlines, and the lecturers' academic details. For example: “internet facilities particularly the intranet and then each department has its own website... they also have a platform for the e-learning... we also have laptops to aid our typing, preparing power point and use of projector" (A12). These suggest that e-learning facilities in M-University are adequate and no other facility should be introduced at the moment rather the facilities should be regularly updated and maintained, and this is the reason why most lecturers are adopting them in delivering their lectures. These findings agree with who stated that for an institution to be able to adopt e-learning, it must provide adequate and reliable technical infrastructures.

\section{Utilization of e-learning facilities}

Our earlier findings showed that M-University has adequate facilities and should regularly improve and update them. As indicated by some lecturers; "Yes, very well sir... New facilities shouldn't be introduced at the moment except for the consistency of the internet and then accessing of the e-book... Once we can perfect the challenges of what we have on ground then we can think of introducing new facilities but when we

Table 8 Preference and ease of e-learning adoption over 'face to face' method

\begin{tabular}{|c|c|c|}
\hline Codes & Themes & Sample supporting evidences \\
\hline \multirow[t]{3}{*}{$\begin{array}{l}\text { Ease in the use } \\
\text { of e-learning facilities }\end{array}$} & $\begin{array}{l}\text { At ease in using e-learning } \\
\text { facilities }\end{array}$ & $\begin{array}{l}\text { "Whenever I use it I feel comfortable". (A2) } \\
\text { "Absolutely comfortable". (A4) }\end{array}$ \\
\hline & User friendly & $\begin{array}{l}\text { "Yes they are. The ones our university have". (A1) } \\
\text { "It is very simple to use". (A15) }\end{array}$ \\
\hline & Significant improvement & $\begin{array}{l}\text { "Yes. It makes the class more interesting to the } \\
\text { students". (A1) } \\
\text { "Yes because students can access lecture material e.g. } \\
\text { video clips after lectures". (A11) }\end{array}$ \\
\hline \multirow[t]{2}{*}{$\begin{array}{l}\text { Preference of e-learning } \\
\text { over 'face to face' method }\end{array}$} & $\begin{array}{l}\text { E-learning supports 'face } \\
\text { to face' method }\end{array}$ & $\begin{array}{l}\text { "E-learning cannot be a substitute it is a support". (A3) } \\
\text { "I can't substitute face to face to e-learning. E-learning } \\
\text { supports face-to-face". (A7) }\end{array}$ \\
\hline & $\begin{array}{l}\text { 'Face to face' method } \\
\text { preferred over e-learning } \\
\text { method }\end{array}$ & $\begin{array}{l}\text { "No because one may not be able to notice a } \\
\text { confused student". (A11) } \\
\text { "I prefer 'face-to-face because its real and then you } \\
\text { would have the opportunity to really look into the } \\
\text { demining of the students". (A12) }\end{array}$ \\
\hline
\end{tabular}


Table 9 Major factors inhibiting the adoption of e-learning facilities

\begin{tabular}{|c|c|c|}
\hline Codes & Themes & Sample supporting evidences \\
\hline \multirow[t]{3}{*}{$\begin{array}{l}\text { Inhibiting } \\
\text { factors }\end{array}$} & $\begin{array}{l}\text { Attitudes of the } \\
\text { users }\end{array}$ & $\begin{array}{l}\text { "Personal attitude. Some people are not used to it and they don't want to } \\
\text { change. Students' attitude too. You send some things to them through mail } \\
\text { or you give assignments they don't access". (A1) } \\
\text { "Laziness, the 'I don't care' attitude displayed by students and some staff". } \\
\text { (A7) } \\
\text { We don't care because the University do not seek our opinion before } \\
\text { buying(A8) }\end{array}$ \\
\hline & $\begin{array}{l}\text { Inadequate } \\
\text { internet facility }\end{array}$ & $\begin{array}{l}\text { "Fluctuation in the internet". (A1) } \\
\text { "Sometimes the internet access is poor making it difficult to access some } \\
\text { e-learning platforms". (A2) }\end{array}$ \\
\hline & $\begin{array}{l}\text { Inadequate } \\
\text { training }\end{array}$ & $\begin{array}{l}\text { "Lack of know-how and we are still new to some". (A6) } \\
\text { "Lack of adequate training". (A7) }\end{array}$ \\
\hline
\end{tabular}

have not then I don't see the need". (A1). As indicated by a lecturer; "Very adequate, nothing should be added because we have not even utilized fully the ones that we have". (A12) and supported by participants A5 and A7. From the findings it shows that M-University has sufficient e-learning facilities that are available for use as this would improve the level of adoption of e-learning facilities. However, these facilities have not been fully utilised as indicated by some lecturers. Also, these facilities should be graded regularly. On the other hand, in as much as there are quite a number of e-learning facilities available in M-University as indicated by the lecturers, the usage of e-learning facilities is on the average.

It was discovered that majority of lecturers in M-University indicated that e-learning facilities are not fully utilized. This may be as a result some factors such as attitude of the users, 'not functional' e-learning facilities, poor internet access and people not wanting to change. The findings show that M-University is still learning and improving in the usage of e-learning facilities. This was in line with some of the comments made by respondents: "I would say average utilization". (A2); "Well M-University is trying though but we have not gotten there yet". (A7) Similar statement was echoed by participant A12 and A9. For M-University to achieve full utilization of e-learning facilities they need to ensure that the facilities are working; and the lecturers are trained on how to utilize e-learning facilities. The finding confirms that e-learning is not fully utilized. This might be as a result of lack of technical know-how and attitudes of the staff. This is in line with the findings of Seiden (2000) and Uhaegbu (2001) which attributed this to low level of usage of ICT equipment and facilities in schools.

\section{Ease in using e-learning facilities}

The findings further indicate that majority of the lecturers are comfortable with the use of e-learning to deliver lectures because the facilities are not too technical to grasp. E-learning facilities are less worrisome in usage and thus, they improve delivery performance. Some lecturers note that: "whenever I use it I feel comfortable" (A2); "absolutely comfortable" (A4); Similar statements were echoed by participants A8, A9, A10. Furthermore the findings revealed that lecturers attest that younger generations are faster adopters. "Yes for a 21st century youth like me" (A12); "They are for young guys like me" (A14). Students can easily grasp what was taught in class; access the 
lecture materials online rather than the traditional printing or hardcopies which is not cost effective. Aboderin (2011) found that the application of ICT in the classroom makes lesson very interesting and easy to deliver. Similarly, Amedu (2014) revealed that e-learning enhances teaching through provision of better researched information, easier storage and retrieval of teaching materials, improved quality of teaching, and provision of platform for teachers to update their knowledge and enhance group learning.

\section{Preference of e-learning}

The findings revealed mixed reaction about the preference of e-learning over face to face method. While some believed that e-learning and 'face to face' method complement each other, others are of the opinion that they still prefer the face-to-face method of delivery to e-learning. However, majority of the respondents indicate that e-learning cannot be chosen over 'face-to-face' method but they support each other. For instance, a lecturer uses the power point to prepare lectures and presents them in the class via projector. Similarly, lecturers get materials online and use them to prepare lectures for the students. Most lecturers assert: "E-learning cannot be a substitute, it complements face to face" (A3); "I can't substitute face-to-face to e-learning: e-learning supports face-to-face" (A7). "Both are needed for effective teaching". (A10); "I use both when the e-learning facility is available for use and working properly". (A9). These revealed that both methods are needed for effective teaching. Falana (2015) indicated that e-learning is an alternative to face-to-face teaching method but when e-learning complements face-to-face teaching method, they both increase collaborative learning and interaction. On the other hand, some lecturers prefer 'face-to-face' method to e-learning method. Some lecturers indicated that: "one may not be able to notice a confused student under e-learning." (A11); "I prefer 'face-to-face because its real and then you would have the opportunity to really look into the demining of the students". (A12). These lecturers are of the opinion that 'face to face' method is most preferred because of the relationship that exist between the lecturers and the students. The lecturer would always want to know how the students are feeling and to know if the students are really paying attention in class. However, from the findings it is obvious that not all the lecturers are using e-learning facilities to deliver lectures to students, and most lecturers that are doing so are the younger ones.

\section{Key factors inhibiting the adoption of e-learning facilities Attitudes of users}

Attitude of users emerged as a major factor that hinders the adoption of e-learning facilities in M-University. Attitudes is the behaviour of the faculty towards adopting e-learning. The findings revealed that some lecturers do not use new technology while others feel lazy to prepare power points after preparing comprehensive notes that can be uploaded online for students to access. "Some lecturers are difficult to change as well as students; materials that are normally sent to them via email are not accessed by them." (A1). "....the 'I don't care attitude shown by some faculty are not encouraging" (A7). Some experienced lecturers lack of interest coupled with the departure philosophy also hinders the adoption of e-learning facilities. For example, "experienced academics do not see reasons to change from the analogue age to the digital age" (A11); "The 
departure philosophy just to do something new is frustrating". (A12). This suggests that changing the mind-set of the lecturers for doing something new is needed. These findings confirm Ilechukwu (2013), which revealed that the greatest challenges for effective utilization of e-learning by teachers include the unwillingness to change to the new method of computer literacy among lecturers and students.

\section{Inadequate internet facility}

The findings indicated that internet facility provided by CSIS is of low quality; network either fluctuates, not accessible or limited in access. Some lecturers assert that "sometimes, the internet access is poor making it difficult to access some e-learning platforms" (A2); "occasional network failure" (A4); Similar statements were echoed by participant A11. These factors significantly affect the adoption of e-learning facilities and need to be corrected by providing accessible and quality internet facilities. When the facilities are inadequate, the megabyte needed to access the internet is limited and the network incessantly fluctuates. It means that the lecturers cannot successfully access the internet. Anene et al. (2014) unveiled some of the challenges to include lack of infrastructures such as computer hardware and software and bandwidth/access necessary for deploying an effective ICT platforms. There are acute shortages of trained personnel who can perform application of software, operating systems, internet access and network administration. However it is suggested that M-University should improve upon their internet facilities by making them accessible and unlimited.

\section{Inadequate training}

Inadequate training means insufficient development of users for e-learning adoption. The findings reveal that M-University users of e-learning facilities are not adequately trained which in turn affects the adoption of e-learning facilities; "lack of know-how and we are still new to some". (A6); "Lack of adequate training" (A7). This was supported by participants A3 and A11. It is obvious from the finding which is $46.7 \%$ of the respondents' perceptions that the lecturers are insufficiently trained; therefore, continuous training should be done to correct this inhibiting factor. This finding suggests that the reason why most lecturers do not utilize e-learning facilities is because of the limited knowledge on how to use the facilities. In their study, Nbina et al. (2011) found that some lecturers have no knowledge of ICT facilities and thus, shy-away from utilizing them for teaching activities. Similarly, Asogwa (2011) found that the major challenges for optimizing e-learning is lack of requisite skills, the teachers are not as skilled and thorough in the understanding, operation and applications of the packages as they are supposed to be. Many lecturers are still not good at powering laptops their laptops, composing and sending e-mails, accessing mails, attaching files and those other peripheral issues. Therefore, M-University should endeavour to conduct periodical trainings for their staff.

\section{Conclusion and implication}

The study attempts to seek instructor/faculty views of the status of e-learning in $M$ University with regards adequacy of e-learning facilities and utilization levels by faculty; preferences and ease of use of e-learning, and factors inhibiting the adoption of 
e-learning. Researchers have identified some of the key issues associated with the adoption of e-learning facilities in one Nigeria University. In general, the findings indicate that $89 \%$ of participants agree that there are sufficient e-learning facilities for use; the facilities are user friendly and the facilitates help to significantly improve learning. However, $72 \%$ of the participants indicated that the attitudes of users, inadequate Internet facility and inadequate training are major inhibitors. The implication is that the University should regularly conduct training especially when new faculty are employed to ensure that they adapt and use them. Furthermore, there should be some kind of weekly monitoring to ensure that lecturers use them in classes at all times.

Availability and adequacy of e-learning facilities is one of the basic requirements for successful adoption of e-learning facilities in private Universities, and for such institution to adopt e-learning successfully, it must provide adequate and reliable technical infrastructures. The findings suggest that although there are quite a number of e-learning facilities available in most private Universities compared to public universities (as indicated by the lecturers), the usage of e-learning facilities in private universities is still on the average. This is as a result of lack of technical know-how and the attitudes of the staff which reveal the low level of usage of ICT equipment and facilities in schools today. From the analysis, majority of the lecturers are comfortable with the use of e-learning to deliver lectures to students because most of the facilities are user friendly which has significantly improve lecture delivery in contrast to the findings of other scholars that have focused their study on public institutions. In addition, while some of the findings suggest that e-learning and 'face to face' method complement each other, and increases collaborative learning and interaction, some participants are of the opinion that face to face method of delivery is preferred to e-learning.

The study also recognises some of the inhibiting factors affecting e-learning adoption. Attitude of the users is one of the inhibiting factors that affect the successful adoption of e-learning facilities by lecturers. Some lecturers are not used to it and they do not want to accept changes because they are afraid of adopting the new technology as old professors do not see reasons to change from the analogue age to the digital age. The implication is that the level of e-learning usage in M University is still on the average. In addition, while other e-learning facilities are available in M-University poor internet facilities was a major challenge. The implication is that lecturer's access to the internet and the megabyte needed to access the internet is limited. Also, limited utilisation of the e-learning facilities is due to limited training as a result of poor knowledge of ICT facilities and lack of requisite skills. The level of e-learning facilities would be improved if quality internet facilities are provided and accessible (Nwokolo and Anyachebelu, 2012).Therefore, school management and government authorities should brace up to these challenges through acquisition and installation of modern e-learning infrastructures and active involvement of e-learning in all school curricula. Also, ICT centres should be established and necessary facilities like computers, web-connectivity and constant electricity supply in the institutions to enhance students' access to e-learning facilities are to be provided and upgraded from time to time. This would improve lecturers' performance and increase the usage of e-learning facilities. In addition, periodical trainings should be organized for lecturers. This would enable them acquire the relevant skills and knowledge on the usage of e-learning facilities (Evoh, 2007; Nwana, 2009). 
The study has some implications. Adoption of e-learning facilities have moved from a simpler adoption participation process to involving various stakeholders in the institution with the university system including the student that constantly interact and influence the process of adoption. Eze et al. (2014) noted that various stakeholders can influence and be influenced by technology adoption and these stakeholders especially the innovative ones are the ones that are the forefront of initiating and influencing the adoption process. Lecturers are not in full utilisation of the available e-learning facilities because most of them are not involved in the decisions making process of its adoption. The university management do not make any effort to listen to understand their needs and requirements. When such facilities are procured some lecturers particularly the experienced ones will abandon it. The implication of this is that adoption of e-learning facilities is a complex process requiring significant attention and interactions among various internal and external stakeholders who impact on the adoption process. Hence the study identifies the importance of individual factors influencing the adoption of e-learning, and the underlying message has emerged that the level of e-learning adoption will improve if tertiary institutions recognise the social dimensions of e-learning adoption such as interest and needs, academic and professional goals, pattern of work source of support and social network (Singh and Hardaker, 2014).

In the design and implementation of e-learning facilities, past studies noted that e-learning experts have always relied on methods that are structured in order to get information requirement from various stakeholders and users of the facilities (see Orlikowski and Gash, 1994). Hanseth and Monteiro (1997) have argued that these approaches do not pay sufficient attention to the assumption, expectations, values and beliefs and how this may impact various stakeholders who are the end users of the technology. Therefore, this study is useful to the authors (Universities and IT experts) who are involved in the development of the e-learning facilities so that they can understand how the values, expectations and beliefs differ from the end users of these facilities. The study therefore provides a better understanding of issues associated with the adoption and utilisation mechanisation in tertiary institutions. It unveils the nature of adoption practices that may inform the rapid development of institutional e-leaning structure (Singh and Hardaker, 2014).

Majority of ICT adoption studies deployed quantitative methods. This study creates awareness of diversifying ICT adoption research in terms of theories and methods. The study reveals that there are a number of methodologies that can be used to study emerging ICT adoption from dynamic process perspectives. Using interviews and most especially deploying hybrid approach to thematic data analysis, provides some guideline for eliciting meanings from the data and conceptual ways of examining, analysing and gathering and clustering data into most suitable categories. The implication of using qualitative approach and most importantly the thematic analysis is that in the initial stages of exploring the phenomenon, most times, little is known that even articulating a dependent variable or suitable independent variable is difficult. Also, there are at times the researcher is seeking to describe person, events, groups or culture. This approach helps in making the findings and description clearer and in making the themes or code developed potentially useful to other researchers. In addition, often qualitative research have been abused by researchers who have made it an excuse for sloppy or illogical research, thematic analysis has shown to be a creditable technique for generating richer insights and findings (Boyatzis, 1998). 
Lastly, most often in qualitative research, the size and sample used are limited. This study focuses on one private university, and the size and simple use are limited. These limitations require caution for the generation of the findings. This study requires further validation across a wider population using mix method-a combination of qualitative and quantitative methods. Therefore further studies should collect and collate a large number of data to allow a more reliable generalization. In addition, future research are required in the same type of research with students to counter-check students' voices to provide a more balanced view.

Funding

There is no funding for this paper.

\section{Availability of data and materials}

We would have loved to share the data however, the data is primary in nature and the authors do not wish to share the data as this may breach participant confidentiality.

\section{Authors' contributions}

SCE made substantial contributions to conception and design and drafting the Manuscript and analysis of data. Also involved in revising the manuscript critically in order to meet the journal standard. VCCE and AOB were involved in the acquisition of data and interpretation of data. Both authors also participated in revising the manuscript to address the reviewer's comments'; SCE, VCCE and AOB are accountable for all aspects of the work to ensure that questions associated with the accuracy and honesty of any part of this research are properly investigated and resolved. All authors read and approved the final manuscript.

\section{Competing interests}

The authors declare that they have no competing interests.

\section{Publisher's Note}

Springer Nature remains neutral with regard to jurisdictional claims in published maps and institutional affiliations.

\section{Author details}

${ }^{1}$ Department of Business Administration, Landmark University, Omu-Aran, Kwara PMB 1001, Nigeria. ${ }^{2}$ Michael Okpara University of Agriculture, Umudike, Abia State, Nigeria. ${ }^{3}$ Department of Business Administration, Landmark University, P.M.B 1001 Omu-Aran, Kwara State, Nigeria.

Received: 8 February 2018 Accepted: 12 June 2018

Published online: 19 September 2018

\section{References}

Aboderin, O.S. (2011). The Status Information and Communication Technology (ICT) in Secondary Schools in Secondary Schools in Ondo State (unpublished M.Ed Thesis).

Aboderin, O. S. (2015). Challenges and prospects of E-learning at the National Open University of Nigeria. Journal of Education and Learning, 9(3), 207-216.

Aboderin, O. S., \& Kumuyi, G. J. (2013). The problems and prospects of E-learning in curriculum implementation in secondary schools in Ondo state, Nigeria. International Journal of Educational Research and Technology, 4(1), 90-96.

Ahmed, T. (2010). E-learning as a new technological application in higher education and research: An empirical study and proposed model. The International Academic Research Journal, 2, 2-13.

Al-Gahtani, S. S. (2016). Empirical investigation of e-learning acceptance and assimilation: A structural equation model. Applied Computing and Informatics, 12(1), 27-50.

Allen, I.E \& Seaman, J. (2003). Sizing the opportunity; the quality and extent of online education in the United States, 2002 and 2003. Wellesley MA: The Sloan consortium.

Anene, J. N., Imam, H., \& Odumuh, T. (2014). Problem and Prospect E-learning in Nigerian universities. International Journal of Technology and Inclusive Education (IJTIE), 3(2), 320-327.

Asogwa, C. I. (2011). The Challenges of Optimizing e-Learning Opportunities for Effective Education Service Delivery in University of Nigeria Nsukka. In O. Nkad, \& U. Eze (Eds.), Optimizing e-Learning Opportunities for Effective Education Service Delivery. Nsukka: Publication of Institute of Education University of Nigeria.

Atsumbe, B. N., Emmanuel, R., Igwe, C. O., \& Atsumbe, J. (2012). Repositioning vocational and technical education for effective manpower production in Nigeria. IOSR Journal of Mechanical and Civil Engineering (IOSRJMCE), 1(4), 01-06.

Awa, H. O., Eze, S. C., Urieto, J. E., \& Inyang, B. J. (2011). The upper echelon theory (UET): A major determinant of information technology adoption by SMEs in Nigeria. Journal of Systems and Information Technology, 15(6), 278-295.

Bates, S. R., \& Jenkins, L. (2007). Teaching and learning ontology and epistemology in political science. Political Studies Association, 27(1), 55-63.

Bates, T. (2007). Technology, e-learning and distance education. In British Journal of Educational Technology 37 (6) 975 _976.

Bhuasiri, W., Xaymoungkhoun, O., Zo, H., \& Rho, J. (2012). Critical success factors for e-learning in developing countries: A comparative analysis between ICT experts and faculty. Computers \& Education, 58, 843-855.

Boyatzis, R. (1998). Transforming qualitative information: Thematic analysis and code development. London: Sage Publication Ltd. 
Bukhari, R. A. (2010). Information technology for e-Learning in Developing countries, (pp. 1-85). School of Business and Informatics: University of Boras.

Chen, H., \& Tseng, H. (2012). Factors that influence acceptance of web-based e-learning systems for the in-service education of junior high school teachers in Taiwan. Evaluation and Program Planning., 35, 398-406.

Chiaha, G. T. U, Eze, J. U., \& Ezeudu, F. O. (2013). Education students' access to E-learning facilities in universities southeast of Nigeria. Information and Knowledge Management, 3(10), 32-41.

Choudrie, J., \& Dwivedi, Y. K. (2005). Investigating the research approches for examining technology adoption issues. Journal of Research Practice, 1(1), 1-12.

Chuang, T.-T., Nakatani, K., \& Zhou, D. (2009). An exploratory study of the extent of information technology adoption in SMEs: An application of upper echelon theory. Journal of Enterprise Information Management, 22(1/2), 183-196.

Elliot, S., \& Loebbecke, C. (2000). Interactive, inter-organisational innovation in electronic commerce. Information Technology and People, 13(1), 46-66.

Evoh, C. J. (2007). Policy networks and the transformation of secondary education through ICTs in Africa: The prospects and challenges of the NEPAD e-schools initiative. International Journal of Education and Development., 3(1), 24-30.

Eze, S., Duan, Y., \& Chen, H. (2012). Factors Affecting Emerging ICT Adoption in SMEs: An Actor Network Theory Analysis. International Conference on E-business Technology \& Strategy (ICETS). China: Tanjin.

Eze, S., Duan, Y., \& Chin, H. (2014). Examining Emerging ICT's Adoption in SMEs from a dynamic Process Approch. Information Technology and People, 27(1), 63-82.

Eze, S. C., Awa, H., Okoye, J., Emecheta, B., \& Anazodo, R. (2013). Determinant factors of information communication technology (ICT) adoption by government-owned universities in Nigeria: A qualitative approach. Journal of Enterprise Information Management, 26(4), 427-443.

Eze, S. C., \& Chinedu-Eze, C. V. (2018). Examining information and communication technology (ICT) adoption in SMEs: A dynamic capabilities approach. Journal of Enterprise Information Management, 31(2), 338-356.

Falana, F. T. (2015.). Prospects and challenges of e-learning in nigerian university education using national open university of nigeria akure study center. Akoko: department of science and technical education (computer education unit) adekunle ajasin university akungba akoko.

Garrison, D. R., \& Anderson, T. (2003). E-learning in the 21st century: A framework for research and practice. London: Routledge/Falmer.

Hanseth, O., \& Monteiro, E. (1997). Inscribing behaviour in information infrastruture standards. Accounting, Management and Information Technologies, 7(4), 183-211.

Hu, P. J.-H., \& Hui, W. (2012). Examining the role of learning engagement in technology-mediated learning and its effects on learning effectiveness and satisfaction. Decision Support Systems, 53(4), 782-792.

llechukwu, L. C. (2013). The assessment of utilization of e-learning opportunities for effective teaching and learning of religion in Nigerian tertiary institutions. European Journal of Education Studies, 5(3), 343-359.

Kajetanowtez, \& Wierzejewski (2010). Why multinationals contribute to ICT education to bridge the digital divide: Synergies between business benefits and socio-economic development in emerging economies. In Master's thesis, Erasmus University.

Keramati, A., Mofrad, M., \& Kamarani, A. (2011). The role of readiness factors in e-learning outcomes: An empirical study. Computer \& Education., 57, 1919-1929.

Kizito, B. J., \& Bijan, K. (2006). An empirical study on education strategy to E- learning in developing countries. Proceedings of 4th IEEE International Workshop on Technology for Education in Developing Countries (TEDC06).

Kotler P. (1984) Marketing Essentials. Englewood Cliffs, NJ: Prentice-Hall.

Lee, Y. (2003). The technology acceptance model: Past, present and future. Communication of the Association of Information Systems, 12(50), 752-780.

Liverpool, L.S.S., Marut, M.J., Ndam, J.N. \& Oti, D.A.(2010) Towards a model for e- learning in Nigerian HEls: Lessons from the University of Jos. Available: www.forum.org.ng/system/files/ifepresent.vff_.pdf (October 2, 2013).

Maduhusudhan, M. (2008). Use of UCC internet e-journals by research scholars and students of university of Delhi. Library Hi Tech, 26(3), 369-386.

Maldonado, U., Khan, G., Moon, J., \& Rho, J. (2011). E-learning motivation and educational portal acceptance in developing countries. Online Information Review., 35, 66-85.

Markus, M., \& Robey, D. (1998). Information technology and Organizational change: Causal structure in theory and research. Management Science, 34(5), 583-598.

Miles, M. B., \& Huberman, A. M. (1994). Qualitative data analysis: An expanded sourcebook. Thousand Qaks: California, Sage Publication Ltd.

Naidu, S. (2006). e-Learning: A Guide book of Principles, Procedures and Practices. Asia: Common Wealth Education Media Centre for Asia.

Naqvi, S. H. (2007). Use of electronic resources of Jamia Millia Islamia (a central university): A case study. NACLIN., 320-324.

Nbina, J. B., Obomanu, B. J., \& Vikoo, B. (2011). Utilization of information and communication technology for quality instruction in rivers state university of leducation Port Harcourt. An assessment. Journal of Emerging Trends in Educational Research and Policy Studies (JETERAPS)., 2(1), 74-80.

Nwokolo, A. A., \& Anyachebelu, E. F. (2012). Availability and use of information and communication technology resources for counselling university students in south east states, Nigerian. International Journal of Humanities and Social Sciences, 2(7), 220-225.

Oguzor, N. S. (2011). E-learning technologies and adult education in Nigeria. Educational, (pp. 347-349). Research and Reviews.

Olojo, O. J., Adewumi, M. G., \& Ajisola, K. T. (2012). E-learning and its effects on teaching and learning in a global age. International Journal of Academic Research in Business and Social Sciences., 2(1), 203-210.

Orlikowski, W., \& Gash, D. (1994). Technological frame; making sense of information Technology in Organization. ACM Transactions on Information Systems, 12(2), 174.

Salawudeen O S (2006) E-learning technology: The Nigeria experience, Shape the Change XXIII FIG Congress Munich Germany, October 8-13, 2006207. 
Seiden, P. A. (2000). Where have all the patrons of ICT gone. Reference and User Service Quarterly, 39(3), 210.

Silva, L. (2007). Post -positivist review of technology acceptance model. Journal of the Association for Information Systems, 8(4), 255-266

Singh G., and Hardaker G. (2014) Barriers and enablers to adoption and diffusion of e-Learning, Vol.56, N0:2/3, pp.105-121

Sloan D., Porter E., and Robins K and McCourt K (2014) Using e-learning to support international students' dissertation preparation. Vol 56, No: 2/3, pp.122-140

Uhegbu, A. N. (2001). Deterrents to information service for community development. Library Review, 50(5), 237-242.

Wang, T. (2009). Rethinking teaching with information and communication technologies (ICTs) in architectural education. Teaching Teacher Education., 25(8), 1132-1140.

Zhang, Q., Lu, C., \& Boutaba, R. (2010). Cloud computing: State-of-the-art and research challenges. Journal of Internet Services and Applications, 1(1), 7-18.

Submit your manuscript to a SpringerOpen ${ }^{\circ}$ journal and benefit from:

- Convenient online submission

- Rigorous peer review

- Open access: articles freely available online

- High visibility within the field

- Retaining the copyright to your article

Submit your next manuscript at $\gg$ springeropen.com 